\title{
Moral Education in Secondary Schools: What, how, and why?
}

\author{
Tomáš Hejduk
}

\begin{abstract}
The paper argues for a philosophical approach to the teaching of moral education in secondary schools. Because students at this level are already capable of conceptual thinking, but are still at a formative stage, teachers can encourage them in their autonomous thought and life orientation through reference to meta-ethical authorities. In terms of these authorities, students may be led to find that there is something (beauty, truth, goodness) other than the ordinary, narrow concerns of everyday life. At the same time, truth or beauty should be unveiled in everyday life; ordinary matters such as language must be revealed as moral concerns, and be liberated from vulgarity. For this to provide a sufficient experience of things beautiful and good, I argue, the ethos of moral education at secondary schools should reflect the ethos of the university. I also argue that we need this kind of education to counterbalance the expanding informational and consumer character of our society, and to give meaning to the life of every participating individual. Finally, I warn against doctrinal simplification, specifically, the misuse of the liberal spirit of the university and moral education (using the example of the Czech National School Curriculum).
\end{abstract}

Keywords: secondary school; moral education; virtue ethics; the idea of the university

This paper discusses the teaching of moral education in secondary schools, i.e. to students approximately between the ages of 15 and 18. I focus on secondary schools because students here are still considerably open and formative and at the same time they are able to think conceptually, systematically, and fundamentally (to open themselves to meaning and the whole - see below). Mainly, secondary school is, for most people, the last place where they can rightfully deal with the "impractical" matters that are so important for their life: this "impractical spirit" also associates secondary school with the idea of the university. For a more detailed account, see Hejduk, 2012.

The thesis of the paper rests on the need for a philosophical approach to the teaching of moral education in secondary schools. In accordance with the Platonic and existential tradition today evolved largely through what have been termed virtue ethics and against reductive rationalism (Kantianism, Consequentialism), I insist on the crucial role of the personal inner life, without coming to "her own" constructions and decision making (subjectivism) - as what are termed therapeutic and liberal approaches do - but by condi- 
tioning this inner life through the experience of the sanctity, beauty, and goodness of life and the world (see neo-Wittgensteinians, the Swansea school, etc.). Moral education in secondary school, according to my argument, should not be afraid of such reference to the meta-ethical order (formulation of the goal or meaning of the human agency and value scale) and its development, for example by introducing possible meta-instances (authorities) that can represent solid ground for moral thought and agency. In actual discussion of this position (see, for example, Kilpatrick, 1992; Hábl, 2015; Lickona, 1992; Thiessen, 1993), I tend toward metaphysical realism and character education that grounds moral education in a conviction that it is possible to find an underpinning in the world that contains values and orientation (beauty, good). In this paper, I support these modern streams in the philosophy of education through reference to philosophers from the area of virtue ethics (including some Czech philosophers).

In terms of methodology, the paper has a normative character. Using descriptions of the state of affairs, it gives reasons for the propriety of approximation to a certain ideal position, which is also supported on the basis of the principle of the explanation of the lower from the higher (e.g. the higher moral order being motivation and merit for an individual's effort). I keep to the same principle in explaining secondary education, with a distinct regard for the idea of the university. Such an explanation is part of the argument that the present moral and intellectual crisis might be resolved by the ethos of the university, and by ensuring care for the above-mentioned experiences of beauty, goodness, and truth.

The structure of the paper is as follows: the first part defines what should be taught at secondary schools (guidance on becoming autonomous and how to see thinking and language as moral matters) under the existing conditions of our society (post-liberal democracy, information and consumer society). The definition of the core of moral education is also used to draw conclusions about the methods and objectives (not simply teaching students the history and individual theories of ethics or how to behave decently, but above all sparking a zest for life, as well as a personal interest in ideas and values).

The second part of the paper explains how the ongoing crisis of our democratic society, caused by the lack of a deeper or more holistic value orientation, relates moral education to the theory and interpretation of the meaning of life. Therefore, moral education cannot be used as a tool subordinated to anything else. However, there exists one setting that helps to define and cultivate values, namely, the ethos of the university and science. Many scholars believe that this ethos can create or establish the ethos of the entire democratic and civilized society. In this context, this part of the paper describes the nature of the university as a possible breeding ground for teaching moral education at secondary schools.

The final part, as an example of autonomy, individualism, and other no- 
tions developed in the paper, deals with the criticism of one tendency of the Czech National School Curriculum, which poses the threat of the increased influence of ideology and the misuse of the liberal spirit of science and the university, which is otherwise - in the paper - considered to be the basis of moral education.

\section{INNER REFINEMENT AS BOTH}

\section{A UNIVERSAL AND SITUATIONAL GOAL}

The aim of moral education taught at secondary schools must be understood in the context of the current situation: on a general level, the role of moral education in a good era differs from its role in a bad one. ${ }^{1}$ On a more specific level, it also depends on the cultural, social, or political state of affairs. (There are other perspectives, such as the type of students, the local situation, etc., that will not be covered in this paper.) On another level, there are certain ethical codes and norms that may qualify as ethical universals and that should always be refined, regardless of the situation. This, however, does not mean that ethical universals are not situation-specific: even the supreme universal, "morality as the attempt to decrease the amount of suffering among human beings" (Rorty, 2000, p. 110), does not mean anything unless there is someone to promote it and refine it in the here and now - unless the teacher is able to show topical examples of cruelty - as well as to stimulate students' imaginations in order to help them look for new examples of impoverishment in a new situation. To express this more generally, given that good ethics and moral education are always a part of philosophy: "There are many true and obvious things to be said in the face of the world's horrors, and many kinds of writing can and should say those things in an obvious way - but these are not usually the things that philosophy, if it is to be helpful in its special ways, has reason to say; or if it does on occasion have reason to say those obvious things, it will be its reason for saying them that will not be obvious." (Williams, 2006, p. 213).

\section{The post-liberal condition}

The role of moral education in a bad era will be dealt with later on; first, the existing, "good" state of affairs will be described in more detail. We live in a post-liberal democracy. In such a society, moral education cannot "impose" readymade norms, rules, and principles, i.e. it cannot be "a subject that aims to define how to live and what human and social principles to apply". ${ }^{2}$ Instead, moral education should stimulate, maintain, and promote students' personal and inner growth, questing, and refinement. This approach is further warranted by one of the biggest dangers in today's society,

\footnotetext{
1 Hejdánek (1988) quoting L. Wittgenstein, Vermischte Bemerkungen, p. 141.

2 Eurydice, Information on Education Systems and Policies in Europe. For an electronic version, see www.eurydice.org. I quote from Svobodová, 2012, p. 104.
} 
which is linked to its transformation into an information and knowledge society. The shift towards information and knowledge entails the threat that any education, including moral education, will boil down to a mere transfer and storage of information, norms, knowledge, and principles, lacking any context or connection to the larger whole. Such a shift downplays the value of understanding and knowledge on its own, and sees its value only when applied in the here and now. ${ }^{3}$ The challenge we currently face is how to retain the wisdom that stands in the background of the advances made by humans in their quest for knowledge (advances achieved as by-products, rather than as ends): like the wise and spiritual elves in The Lord of the Rings, our ancestors made rings (i.e. scientific and technical advances) that they passed on to us, their descendants, and to the whole world. Such gifts should mean that their heirs would continue to engage in the spiritual heritage of their ancestors, rather than mindlessly accepting readymade knowledge and advances that will be used regardless of the wisdom that gave rise to them (Grygar, 2005, pp. 65-66).

In fact, there are other features typical of the information or consumer society behind the shift towards wisdom or deep knowledge: never before have we had such easy, even omnipresent, access to such a huge amount of information, and never before have we produced so much information. Such an overproduction and overload of information must be counterbalanced, to say the least, by thinking that will make it possible to critically classify, process, and develop the information in the lives of both individuals and society, despite the existing reign of business and despite the fact that (i) the growth of the disposable amount of knowledge, interestingly, results in poorer and less applicable learning outcomes, as well as reduced creativity and room for a free life, and (ii) the social and political debate has not become wider and more civilized (Petrusek, 2007, pp. 3-5). ${ }^{4}$

The principle of inner refinement, as opposed to external indoctrination, is both based on the condition and character of today's society and an example of an ethical universal that constitutes an exception to the lack of completeness and controllability of moral education and ethics as such. There are two aspects to explaining the principle, as outlined below.

\section{Guided autonomy and thought and language as a moral matter}

The first aspect encompasses guidance on becoming autonomous, i.e. on the inner movement of the mind, which shows individuals their own existence, i.e. life as a whole (from the perspective of one's own finiteness and world horizon). In terms of a moral education still based on the fun-

\footnotetext{
3 This issue has been dealt with by thinkers since time immemorial. For example, think of the ironic statements by Heraclitus about knowledge of individual pieces (historiá) and broad education (polymathié), which will not teach you wisdom: e.g. B40: "The learning of many things does not teach understanding."

4 Referring to Langdon Winner and his three paradoxes of the information age: Winner, 1994.
} 
damental question formulated by Socrates, "How should one live?", it is necessary to think about the overall meaning of life. The relation to the whole creates a "shake", which leads to an experience of the meaning of life, or at least an opening up to it (Patočka, 1996, pp. 378-381). Autonomy in this context, then, means the capability of one's own critical thought, and the resultant decision making, but only through the responsibility to, and deep relationship with, others (e.g. discussion), including the meta-ethical authorities (see below). ${ }^{5}$

The second aspect resides in the discovery of thinking as the core of human life (i.e. not only as a servant or a tool), and in understanding language (which is a prerequisite for thinking) as a moral matter. Students should understand that they must keep their word, not only out of politeness but especially because humans are, in fact, what they say (for example, if you repeatedly fail to wait at a place where you promised to meet someone, then you will gradually cease to exist in that person's life). Moreover, we must understand what we actually say/think (from the historical perspective, we must be able to suffer an interview with such an insistent and humiliating interviewer as Socrates), i.e. as an attenuation or explanation of such autonomy, to see that there is a perspective other than our personal one, and that our perspective and identity are created by something that is beyond the scope of the personal: "A thought is not a mere view or impression but rather the soul sticking to important things for as long as necessary for the spark of real clarity to appear in the soul from common dwelling with them." (Patočka, 1996b, p. 120). ${ }^{6}$ A good teacher of moral education makes students think like this, helping them to see and guiding them towards a "monumental vision" that attracts the soul. In this sense, moral education involves commands; however, "moral commands are such commands that are related to inner requirements of thinking as such" (Patočka, 2012, p. 26).

Now we see that the refusal to "impose" or to indoctrinate indeed suggests what has been termed therapeutic and liberal pedagogy (Hábl, 2015, p. 71ff). Nevertheless, in comparison to its non-directive approach, the individual in our conception is not left to search for and develop her own values and construct her own morality. Similarly to what has been termed character education, the individual is expected to "contemplate" something supra-personal, which might be seen by and shared with others, and which might somehow be linked with our ancestors' activities, or might at least orient us in the direction pursued by our ancestors and in which it makes sense to continue with regard

\footnotetext{
5 See, for example, Thiessen's autonomy as a rational, self-possessed, and self-guiding reflection (Thiessen, 1993, pp. 118-119). By "meta-ethical authorities" I mean those authorities who have the potential to provide answers to "meta-ethical questions", such as the meaning or goal of our actions or our life; in the European tradition these include, for example, the Christian god.

6 With reference to Plato's Epistles (341c-d): "There does not exist, nor will there ever exist, any treatise of mine dealing therewith. For it does not at all admit of verbal expression like other studies, but, as a result of continued application to the subject itself and communion therewith, it is brought to birth in the soul on a sudden, as light that is kindled by a leaping spark, and thereafter it nourishes itself."
} 
to future generations. Very generally, there is a trust in moral order that the individual "only" has to see and evolve in her own way. In this manner, we can speak of obligation and responsibility, firstly on the meta-ethical level (transcendent or metaphysical), and only secondly on the social and individual level (the adherence to moral order is greater than that to one's own convictions, desires, or social customs, which might have very diverse, sometimes doubtful sources, motivations, and outputs in the here and now). The teacher, in short, does not dictate norms and values, but together with students reaches for them or allows herself, in a reasonable measure, to be possessed by them. Thus, the rejection of indoctrination is not a rejection of the "outer" infliction (of teacher, other human beings, society, or meta-authorities). The responsibility of the teacher has at least four angles (that are part of every situation, which is solved as a moral issue): a) the responding "me" (e.g. the teacher); b) the instance, to which "I" respond (e.g. the state, God); c) "I", for whom I am responsible (e.g. the student); and d) the matter for which I am responsible (e.g. education) (Hejdánek, 1990, p. 17).?

\section{Narrow-mindedness vs. daily wonder}

If the teacher succeeds in opening up the minds of the students so that they quest "autonomously" and "impartially" (i.e. think for themselves) for who they are or who they can be, who the people around them are, and what they should do with themselves, with others and with the whole world, then the goal of moral education has been achieved. As such, moral education also involves questioning "natural education" and common sense and setting out on a journey of unnatural reasoning and decision making - unnatural because it is painfully unspontaneous and involves extremely systematic questioning, reasoning, and decision making. It is not about learning to respond rightly and accepting natural conditioning, but instead it is about discovering inner power, a spirit able to change oneself and the world (a preference for idealism as opposed to naturalism). This does not imply rejecting traditions and the world in which one has grown up, but rather implies embracing new insights into such traditions and their personal acceptance in a new form. ${ }^{8}$ This is related to the fact that an educated person is more than an informed person (Petrusek, 2007), and it does not mean rejecting learning and the acquisition of knowledge and information - an individual must first know the problems from, preferably, all points of view, both in historical perspective and the current state, to be able to think about and discuss them - but rather combining

\footnotetext{
By "indoctrination" we mean the manipulative restriction of the growth, thought, and decision making of the individual, even if only in the space described in this paper. A similar concept of indoctrination is described in Thiessen, 1992.

8 In this respect, Derrida says that these days only one type of fidelity is possible, which is unfaithful fidelity, by stressing that the traditional approach must be supplemented somehow so that it can be successful under the new circumstances. See Derrida and Roudinesco, 2004.
} 
knowledge and information through an autonomous and holistic approach.

In other words, moral education must be as much about the interpretation and transfer of knowledge and tradition as about the "inner" movement of an individual, which is related to leaving behind naive, natural, and narrow-minded everyday concerns (Patočka, 1996, p. 367). To put it simply, a personal interest in an idea, and consequently an interest in life, must be sparked in students. Traditionally, this has been linked to sparking amazement and embarrassment, which has been known since Plato, and has been repeatedly stressed by today's educators: for instance, Holland provides a thorough explanation of how good teachers - and let us stress that teachers of moral education are in the first place - must show that "a man can be at home in the world, find it a good world despite the ill ... by being brought into contact with forms of understanding and apprehension in which some good is to be encountered, some wonder to be seen ..." (Holland, 1980; Gaita, 2004, pp. 215-235). A moral education teacher need not introduce the students first to famous theories, and then to the history of ethics of moral systems, but rather to the most beautiful and admired things that the teacher has encountered in her life. This may involve examples from the lives of great thinkers that may impact on the students' lives by showing them a direction for the rest of their lives. It is crucial that the teacher "has a positive verve to what makes life meaningful and rich" and that she is able to experience that "a sense of living for a close person, science, religion or art makes life meaningful" (Patočka, 1996, p. 422). Such a journey beyond, or rather inside, everyday concerns, a journey to the preciousness of (human or good) life is only apparently impractical; it was Plato who said that wars and other struggles are not lost because of cowardice, but rather as a result of "ignorance regarding the greatest of human affairs" (Plato, Laws 688c).

Sparking an interest in an idea, and thus in life as such, ${ }^{9}$ does not mean that the teacher simply presents one theory after another, but it does mean that the teacher strives for a permanent deepening of the general understanding of (human) life and its problems, as well as the tragedies, beauties, and noble things related to life, by presenting the theories (and their beauties and meaning) and making students see them as something inherent in their lives. The history of ethics, as well as individual theories, must indeed be taught (e.g. thanks to such teaching, virtue ethics, which is probably the most important ethical theory these days, has been reborn), but they must not be taught by mere reference to past or current authors.

9 Cf. "zest for life", referred to by Teilhard de Chardin, or "reverence for life", referred to by R. Gaita, and today's absence and underestimation of care for zest for life mainly (but not only) in moral education. Plato's Laws (688c ff.) recommend care for balance between prudence, intelligence, and opinion, with eros and desire following upon these, because otherwise "it is dangerous for one who lacks intelligence to pray, and the opposite of what he wishes comes to pass". 
In moral education, abstract explanations of different systems and approaches should be supplemented with the moral efforts exerted by specific historical personalities. This will make these approaches relevant not only per se, but also for the life and the meaning of life of the student: in moral education, "part of the struggle of a human for oneself, for understanding oneself, and for having a clear idea of oneself takes place. And we want to apply this approach to ethical thinking and to the perspectives that we see as relevant for the present. In other words, ethics will be seen as part of philosophical anthropology, or, say, the anthropology of a historical personality engaged in making history, and we will strive to live together as part of the inner struggle of the European people ..." (Patočka, 1996a, p. 354).

However, a critical approach to the proper teaching of moral education is critical of moral education as such: in the subject, the teacher is exposed to questions not only about what makes moral education important, or even imprescriptible, but also where the limits of moral education lie - for example, what other things are important in life, what ideas or fields may govern life (e.g. beauty, love ...). Today, motivation may not be divided into the moral and prudential, as neither of these applies to long hours of piano practice, for example, and yet we understand and support it (Chappell, 2014, p. 193). Moral education cannot guide students towards being active, responsible, and life-enjoying, as well as to revering the self, by value knowledge or a system of moral principles, nor even through rigid didactic methods and preset agendas: "this would rather prevent students from learning that they are themselves an act ... as everything is dead ... ready-made rule." (Patočka, 1996, p. 402).

\section{MORAL CRISIS AND DEFECTIVE} INTELLECTUAL WORK

Today's free and democratic EuroAtlantic society finds itself in the midst of a moral crisis. In an era of globalization, this crisis cannot be solved by moralizing and invoking good morals, as the crisis is not one of morals or behaviour, but rather is caused by a lack of new ethical theories and argumentation: "We need a new and convincing interpretation: an interpretation of the era when we were born and of the world that we live in, and most importantly an interpretation of life and the meaning of life." "...the society is not endangered only by the moral decay and impurity, not by dogmatic impurity [...], and more recently not by sloppy logic and scientific-technical dilettantism, but also, and probably more importantly, by incorrect, defective (impure) thought orientation and intellectual work." (Hejdánek, 1994; Hejdánek, 1997, p. 178). Therefore, moral education must by necessity include intellectual work, which is not, however, limited to the reasoning students use when solving specific or general problems (e.g. the current environmental crisis), but rather includes the thinking that guides such reasoning and sees such problems as part of an overall life orientation, as a mat- 
ter of ideas. Moral education must have as its core the finding of a direction in oneself, society, and the world as penetrating to the living core of our times in terms of ideas. In line with the above discussion, moral education never implies identifying oneself with a single worldview, but rather with an orientation among diverse worldviews. The theory constitutes the basis, and specific issues (e.g. marriage and the question of war and peace) must serve only as examples for the application of such theories. Such theories or "contemplation perspectives" are crucial in that they contribute to a basic orientation in the world and create a general theory of values (which is why ethical issues cannot be explained by other sciences, e.g. biology). Pragmatic ethics or applied ethics is always secondary; specific examples (e.g. liability in the case of self-driving cars, or acting in virtual reality) may be used only to demonstrate something more important, or to attract students to more important issues (although there is some space for situatedness and topicality, response to changes). ${ }^{10}$ The issue is, however, that moral education, as well as other subjects (e.g. literature) that may and should be taught for their own sake, is jeopardized by educational reforms that focus on the instrumentalization of education, i.e. on competitive-centred education, on developing human capital (sic!) for future work (utilitarianism in the end results in education being adjusted for life and squeezing autonomous educational culture), rather than on civil, national, cultural, social, and spiritual life (Štech, 2011, pp. 2-4). However, the same principle that applies to universities also applies to grammar schools and similar secondary schools: the truth, beauty, and the good that are dealt with in classes here (moral education courses especially) do not amount to a zero-sum game (when one excels only at the expense of another), but rather their achievement means excellence for everyone involved: “ $\ldots$ truth is a paradigm of a non-zero-sum good ... because the mere fact that $\mathrm{A}$ comes to possess a given truth does not mean that B has less of it" (Williams, 2005, p. 155).

\section{The ethos of science and the university as a remedy: the dignity of mind and the goodness of the world}

This brings us to the fact that Europeans have persistently searched for life and social orientation in science in its true meaning, which also amounts to an "moral education plan" of a sort related to universal principles of democratic life, and is considered to be an ethos, which should rule today's post-industrial society (in a similar vein, the ethos of the Protestant ethics ruled the era of early capitalism), or rather counter the consumer ethos that does not bring enough positive things (Petrusek, 2007, p. 3, 5) - see e.g. Edward

\footnotetext{
${ }^{10}$ John Dewey, a classical proponent of pragmatism, rejected the idea that education be seen "as a readily usable body of knowledge”. See Dewey, 1916, quoted from Petrusek, 2007, p. 5.
} 
Shils or Daniel Bell: "The community of science is a unique institution in human civilization. It has no ideology, in that it has no postulated set of formal beliefs, but it has an ethos which implicitly prescribes rules of conduct. [...] As an imago [an ideal or subjective image], it comes closest to the ideal of the Greek polis, a republic of free men and women united by a common quest for truth" (Bell, 1999, p. 380). ${ }^{11}$

The moral education brought by science, or by universities and schools in which scientific discipline and spirit are nurtured, should also be present in the school environment itself from the moment of the laicization of schools (i.e. the removal of the influence of the church on education). This school environment should cultivate students morally, in addition to classes on moral education, which should develop and deepen the scientific ethos (more often involving humanity and the implementation of charters of human and citizens' rights, e.g. providing education regardless of the place of birth). It is no coincidence that a despairing Primo Levi, disgusted by the lies of the Fas- cist regime, which polluted the public life of Italy before and during World War II, found consolation in chemistry (he himself was a chemist). But it was not just science that provided him with some solace and encouragement; it was university and school and their ethos and discipline as such. When he was escaping from the Fascist regime, Levi "did not turn to chemistry to find truths - to increase the number of his true beliefs. He could have done that by counting the chairs in his room, the buttons on his shirt or the hairs on his arms. He turned to chemistry because it is a discipline whose tradition reveals what it may be to love truth, to serve it and be faithful to it. Because it is possible to love truth and to be faithful to it, it is also possible for lies to pollute and to defile those things which are precious to us and whose value is partly conditioned by our need for truth.” (Gaita, 2004, p. 190) Chemistry, with its love, represents the university and school, the discipline and spirit that does not exist in this genuine form anywhere else. The core of this tradition is a special kind of love and faithfulness to truth. ${ }^{12}$

\footnotetext{
${ }^{11}$ Shils (1997) makes reference to the truth that has a value in itself, apart from any use to which it is put and about a disinterested search for knowledge; the main objective of teachers and scientists lies in the refinement of truth in all the fields they study and teach, and the respect for truth in their practical activities is essential to, and distinctive of, their calling. On a general level, societies based on democracy and justice may contribute the most, even in ethics, by "their primary activity of discovering and teaching the truth as scrupulously and as methodically as they can."

${ }^{12}$ What is this truth, faith, and love? Even if we can say with Gaita that this truth is food for the soul, it is not a private thing. Why? Because it moderates, it cures public wrongs, and - as our experience with life in the communist regime has taught us - "a private good is no remedy for a public wrong". Or rather we should say that our soul is not a private thing, so the remedy for it must be public or even cosmic, worldly, universal ex definitione. This is precisely where we can see one very good sense of university and secondary school moral education: it is the sphere of love, truth, and discipline, which can provide us with a remedy and may be something more for a polluted political, national, and personal life.
} 
Let us turn to the ethos of science, or to the university, which I believe should also be central to the teaching of moral education in secondary schools. What other characteristics, intentions, and ideals does this ethos have, in addition to those mentioned above? First of all, "liberal" education at a university or secondary school, in contrast to occupationally-oriented vocational education, implies an action upon our mental nature and the formation of our character: it is an "education to perfect gentlemanship, to human excellence [...] consists in reminding oneself of human excellence, human greatness ..." (Strauss, 1995, p. 6) It forms our character; as students we obtain a disposition for thought and habit that will continue for our whole life, and part of this is honesty, deliberation, temperance, prudence, discretion, and philosophical disposition. Moreover, this reminder of our excellence has a cosmic or worldly extension: "By becoming aware of the dignity of the mind, we realize the true ground of the dignity of man and therewith the goodness of the world ... which is the home of man because it is the home of human mind." (ibid, p. 8)

All these formations constitute restrictions and liberations at the same time, or rather, in their restrictive char- acter they all mean the acquisition of personal freedom, which is so important. Here is a more trivial example of such a freedom: while out of school (Newman, who is paraphrased here, refers to the university, but it is presupposed that a good secondary school constitutes a very similar milieu), a man is in danger of being absorbed and narrowed by his pursuit, while at school a teacher knows where the respective subject stands, because he has conducted a survey of all knowledge; "he is kept from extravagance by the very rivalry of other studies, he has gained from them a special illumination and largeness of mind and freedom and self-possession, and he treats his own in consequence with a philosophy and a resource, which belongs not to the study itself, but to his liberal education." (Newman, 1996, p. 167). In a broader perspective, such liberation also has a cultural and political dimension: liberal education, as we know, is "the ladder by which we try to ascend from mass democracy (and what else was Nazism or fascism) to democracy as originally meant" to democracy, which is the opposite of the mass, democracy that is based on insight and perspective, on devotion, discipline. ${ }^{13}$

Levi's consolation in chemistry also meant that the anti-Fascist struggle, in

\footnotetext{
${ }_{13}$ Strauss (1995, p. 8) further states: "Liberal education, which consists in the constant intercourse with the greatest minds, is a training in the highest form of modesty, not to say of humility. It is at the same time a training in boldness: it demands from us the complete break with the noise, the rush, the thoughtlessness ... It demands from us the boldness implied in the resolve ... to regard the average opinions as extreme opinions ... Liberal is liberation from vulgarity. The Greeks had a beautiful word for "vulgarity"; they called it apeirokalia, lack of experience in things beautiful ..."
} 
a broader sense, represented a scientificethical basis of the civilized life of society: "the training of the intellect, which is best for the individual himself, best enables him to discharge his duties to society"; secondary schools as well as universities have a practical impact too, because their art is "the art of social life, ... raising the intellectual tone of society, cultivating the public mind, purifying the national taste, supplying true principles to popular enthusiasm and fixed aims to popular aspiration, giving enlargement and sobriety to the ideas of the age, facilitating the exercise of political power, and refining the intercourse of private life. It is the education that gives a man a clear conscious view of his own opinions and judgments, a truth in developing them, an eloquence in expressing them, and a force in urging them. It teaches him to see things as they are, to go right to the point, to disentangle a skein of thought, to detect what is sophistical, and to discard what is irrelevant." (ibid, pp. 177-178)

At the same time, it is true that neither schools nor universities can be reduced to their social role only, because they are places where adolescents come to find happiness and flourishing (eudaimonia). Oakeshott expresses it ingeniously: "the characteristic gift of a university ... the interval ... is an opportunity to put aside the hot allegiances of youth without the necessity of at once acquiring new loyalties to take their place. Here is a break in the tyrannical course of irreparable events; a period in which to look round upon the world and upon oneself without the sense of an enemy at one's back or the insistent pressure to make up one's mind; a moment in which to taste the mystery without the necessity of at once seeking a solution." (Oakeshott, 2003, p. 28) It is precisely such a release that Levi looked for in chemistry, and that every true teacher or scholar looks for in truth, by which they try to escape the uncontrollable obligations of the world. This sort of truth is warranted; it is available whenever one needs it although its well-known character is impossible to articulate entirely and for all time. Its worldly form represents the truth as a witness, the truth of which the opposite is not a lie, but false witness, injustice, wrong.

As for the scientific and university ethos, it should also be the core of the ethos of a good secondary school (a generalist one) - and moral education should be a subject par excellence in this respect, because (i) it must in itself be an example of knowledge governed by the scientific criteria of the field and created in a scientific community, rather than of knowledge demanded by the needs of the market, or political or social needs; and (ii) it must disseminate such knowledge, of which it is an example, as a more general democratic truth-seeking ethos into (even nonscientific) society. In other words, the cultivation of humans, including their moral development, has traditionally (from Plato through the Renaissance 
humanistic ideal to modern scientific enlightenment) been related to the perspective of reason and science (Gutschmidt, 2010), which means that moral education is not sufficient in itself when viewed in isolation from other subjects, but instead must be based on the discipline brought by other subjects, and by the perspective of beauty and truth in such courses (literature, natural sciences, mathematics, etc.). On the other hand, the association of moral education (and ethics or philosophy) with science and the perspectives of reason cannot mean subordination to them, or to natural and technical science. If so, it would mean scientism: the improper implementation of scientific methods in the field of the "humanities", where against science "we need concepts and explanations which are rooted in our more local practices, our culture, and our history, and these cannot be replaced by concepts which we might share with very different investigators of the world". No scientism will help us with "the issue of how to make the best sense of ourselves and our activities" - its predictive and technological successes mean nothing here. Moral education as part of the discipline called philosophy "should not try to behave like an extension of the natural sciences (except in the special cases where that is what it is), ... it should think of itself as part of a wider humanistic enterprise of making sense of ourselves and of our activities" (Williams, 2006, pp. 186197). Furthermore, since Plato there has been an agreement that what can help nations, countries, and humans is not technical-pragmatic education, but rather moral and spiritual refinement. Only such a refinement aims higher, be it at the personal level or the level of humanity: technical subjects do not (aim to) turn all people into technicians, whereas moral education is relevant for everyone and aims to change the lives of everyone, i.e. to bring them to their better self, and to a better personal and social life (Hejdánek, 1988).

\section{Limits of the "liberal" educational plan}

The final part of this paper will clarify the references made earlier to the "liberal nature" of the scientific and university ethos, or moral education, by showing how complex it is, at least in some of its contemporary versions. For example, the present culture of neoliberalism (which relatively prevails in the Czech Republic) suppresses some promising democratic values that have been recognized in the past. By disseminating its "opinions" and "values" (sometimes uncritically, sometimes through wilful manipulation) the political-economic elites and the media constitute a serious threat to moral education in the whole Euro-Atlantic civilization, and not simply in secondary schools. Jan Květina presents a detailed analysis of the outcomes of the educational process defined by the government (the Czech National School Curriculum, CNSC; 
Various authors, 2007) and uses this robust example to warn against "newspeak that fosters uncritical adoption of certain value attitudes in line with unquestionable and positive principles, which, however, serve as a tool of neoliberal rulers to maintain the existing system". Such principles are usually equivalent to vaguely defined gross concepts (democracy, freedom, justice, etc.) that are held to be universal but in fact are misused through the skilful use of language for the benefit of a specific ideology or political-economic interest (Květina, 2016, referring to Štech, 2011). Therefore, teachers must - while preserving the autonomy of education and its anchoring in thinking (see above) - be engaged in good conceptual work and must develop each concept presented to the students as broadly as possible, while sticking to its clear and precise definition. This will prevent its arbitrary use and differentiate it from one-sided and often manipulative uses. ${ }^{14}$ In class, students must be encouraged and guided to develop such concepts and look for their use in the here and now, and to introduce, adjust, and develop the concepts on the basis of (not subordinated to) the immediacy of life and reality, ${ }^{15}$ while employing their imagination to the greatest extent permissible (cf. Hampshire, 2001). Faced with the one-sided interpretations presented by the media and other repre- sentatives of the establishment, students must try their best to find their own untrodden paths. The two above-mentioned principles will make it possible for education to remain autonomous while not necessarily losing its democratic or liberal-democratic orientation, which is demonstrated by the autonomy of education itself and may be developed even further; for example, in moral education this may be done by promoting and developing the supreme democratic principles (a focus on the vulnerable, human rights, etc.).

The interpretation and overuse of human individualism, or the "atomistic view of humans within the framework of possessive individualism", may serve as an example of the one-sided use of a concept (with high value determination) that is otherwise part of democratic society (Květina, 2016, p. $314 \mathrm{ff})$. Its overuse lies in the fact that it is used in situations where it is not appropriate (private interests override the public and social interest, as well as other areas where people get together), which is derived from an interpretation focusing on the material and utilitarian dimensions, while ignoring the spiritual dimension, which is not only an appropriate expansion of the concept, but also an explanation of self-focus. Its earliest formulation is probably that of Socrates: "[V]irtue does not come from

\footnotetext{
${ }^{14}$ For more on the pivotal role of determining and clarifying concepts, see e.g. Gaita, 2004.

${ }^{15}$ Many concepts are only introduced and developed in theory after they have been enforced in practice, e.g. human rights are based on struggles that took place long ago before the concept of human rights was introduced (Komárková, 1997).
} 
money, but from virtue comes money and all other good things to man, both to the individual and to the state." (Plato, Apol. 30b) As regards virtues and moral education, an emphasis on introspection as a way of learning about oneself may be used as an example: this emphasis is misleading, because it ignores the fact that one can never understand oneself or obtain satisfaction without constituting it, and searching for it, in relation to others and together with others. In short, neoliberal manipulation hides and reduces the holistic and social life of humans, which is the only reasonable way to understand the benefits of individualism.

This character of humans based on community life and relationships is ignored, or suppressed, by some learning outcomes: for instance, the CNSC asserts the importance of making decisions with regard to one's needs, of setting life priorities with regard to one's interests, etc. (Various authors, 2007, pp. 10-11, adopted from Květina, 2016, p. 316). This is a typical example of the ideological suppression of the character of humans based on relationships and sociability, while ignoring the conditioning of humans by creating deep relations with others and involvement in social and community life. This approach ignores, or even rejects without any arguments, the fact that the law, freedom, and justice are either for everyone or for no one, i.e. that these are indivisible concepts that one cannot avail oneself of unless others avail themselves of them as well. The same applies to the right opinion, the truth, etc. (Various authors, 2007, p. 39). ${ }^{16}$ Individuals are seen as gifted with true opinions without reference to any sources of the truth; thus, a debate is a contest between individuals and their readymade opinions, ignoring the kind of debate in which the truth is arrived at through debate, without any of the participants having the truth at the beginning (compare the etymology of the Ancient Greek word "dialogos"). All such specific shifts and one-sided attitudes fit into the onesided refusals, belittling, or failure to understand the collective, public, and political conditioning of human growth, education, identity, and freedom (cf. Znoj, Bíba, \& Vargovčíková, 2014, p. 13ff). A good teacher of moral education in today's pluralistic world must at least admit that answers to ethical questions should be sought publicly, in cooperation with others, including the responsibility for others (as well as the responsibility for the matter itself [education] and for the institutions [state, family, etc.] concerned). This involves, however, a practical-political dimension of moral education: the issue of what values should be kept involves, by necessity, a question: how should they be

\footnotetext{
${ }^{16}$ For more details on the analysis of the CNSC, see Květina, 2016, pp. 318-319.
} 
kept and promoted? Any values and norms that the government holds up need the backing of power and the consensus of the citizens. Even such a consensus and promotion is an ethical issue and is involved in all other ethical questions and questions of moral education: how a specific value should be promoted, how others should be persuaded, how they should be developed in a democratic society, etc. The fact that the CNSC partly ignores such questions (my warnings in the final part of this paper do not mean that the CNSC is completely wrongheaded and ideological; my wish is simply to highlight a certain ideological tendency) becomes transparent when it says that teachers are expected to "develop and refine (pupils') personal, local, national, European, and global identity" ${ }^{17}$ This allows for no conflicts, or no impossibility, or no difficulty in reconciling life in global or local worlds, or in virtual or real worlds. ${ }^{18}$ And yet these are the fundamental issues that must be dealt with in moral education classes.

\section{Conclusion}

To sum up, the basic parameter of moral education in secondary school involves support for ethics based on the thesis that the good agency is conditioned by seeing the true reality, that is, by seeing the world and humans as they ought to be (and not only as they are). The question "what?" is answered by the need to let students know about the reality, which is not seen prima facie, and which might yet be discerned and experienced, and which is communicable and intelligible. Students have to be open to it, accept it, and evolve it in their own specific and autonomous way (part of which, nevertheless, consists in their membership in a given community, nation, etc.). This requires an awareness that the true reality is a transcendent reality that will never belong to them, and that they will never completely understand, but is the only solid basis for their life. Such a metaethical anchoring, and related development of a personal interest in ideas and values, should activate moral education

\footnotetext{
${ }^{17}$ Quoted from Květina (2016, p. 321), where identical criticisms are presented.

${ }^{18}$ I believe that Květina's conclusion (referring to Schmitt's need to come up with "a negative stance and identify an external enemy") to be exaggerated: "No one can be a citizen of the world and a patriot at the same time, because these can supposedly be combined only if there are no conflicts; however, when a decision must be made as to whether to prefer a principle of universal humanity or democratic identification with one's community, no compromise can be made any longer" (p. 322). Is it not possible to imagine that an identification with one's community will be part of universal humanity? Alternatively, can the unity, i.e. a combination of both ways of life, be upheld as a sort of tension that is expressed in laws and institutions or other acts of power? For example, the concept of human rights leads to international treaties being signed, rules of conduct with respect to foreigners being introduced, etc. Or patriotism may be an experience that brings people from different countries together as it makes it possible for them to share the same experience of belonging to something that can be called a homeland.
} 
at secondary schools, or at least aid in seeking it as a primary purpose. This is the "how?" question. The true reality ("what ought to be") needs to be reflected in the world around us (Barabas, 1999, pp. 165-166): students need to be shown the possibility of such reflection, which is nevertheless conditioned by their autonomous disciplined endeavour and open mind (for example, by recognizing language as a moral matter or by recognizing the scientific or university ethos as a basic principle of democratic society). They should also see how important their personally and socially specific approach is for the pur- suit of the good and truth; id est, they must be cultivated on all three levels (individual, social, and meta-ethical) at once. Given this interconnection (and the reciprocity of all three levels), we can regard moral education as a component of the way out of the crisis of European civilization. To answer the question "why?" completely, we submit that this education counterbalances the expanding informational and consumer character of our society by evolving the theory and interpreting the meaning of life, and has the ambition to give meaning to the life of each individual and community that participates in it. ${ }^{19}$

\section{REFERENCES}

Barabas, M. (1999). The agent's erosion of value. In V. Havlík (Ed.), Mezi jazykem a védomím [Between language and consciousness] (pp. 157-181). Prague: Filosofia.

Bell, D. (1999). The coming of postindustrial society: A venture in social forecasting. New York: Basic Books.

Derrida, J., \& Roudinesco, E. (2004). For what tomorrow ...: A dialogue. Trans. J. Fort. Stanford University Press.

Dewey, J. (1916). Democracy and education: An introduction to the philosophy of education. New York: Macmillan.

Gaita, R. (2004). A common humanity, thinking about love and truth and justice. London: Routledge.

Grygar, F. (2005). Kritika založeni galileovské vědy v Husserlově „krizi evropských věd a transcendentálnífenomenologii "[Criticism of the founding of Galilee science in Husserl's "crisis of European sciences and transcendental phenomenology"]. Červený Kostelec: Pavel Mervart. Gutschmidt, H. (2010). Von der 'Idee einer Universität' zur 'Zukunft unserer Bildungsanstalten' - Bildungsbegriff und Universitatsgedanke in der deutschen Philosophie von Schiller bis Nietzsche. In J. Stolzenberg \& L. Ulrichs, L. (Eds.), Bildung als Kunst: Fichte, Schiller, Humboldt, Nietzsche (pp. 149-167). Berlin: Gruyter.

\footnotetext{
19 This paper was supported within the project of the Operational Programme Research, Development, and Education (OP VVV/OP RDE), "Centre for Ethics as Study in Human Value", registration No. CZ.02.1.01/ 0.0/0.0/15_003/0000425, co-financed by the European Regional Development Fund and the state budget of the Czech Republic.
} 
Hábl, J. (2015). I když se nikdo nedivá [Even though no one is watching]. Červený Kostelec: Pavel Mervart.

Hampshire, S. (2001). Justice is conflict: The soul and the city (The Tanner Lectures on Human Values, Harvard University, October 30-31, 1996). Princeton University Press.

Hejdánek, L. (1988). Myšlenkový denik [Thought Diary] 31. 12.1988 (pp. 88-1085). Archive of Ladislav Hejdánek.

Hejdánek, L. (1990). Variace a reflexe na témata vězeňských dopisů Václava Havla [Variations and reflection on the themes of Václav Havel prison letters]. Listy, 20(6).

Hejdánek, L. (1994). Separát. Ř́mský klub [Reprint. Roman Club]. In L. Hejdánek, Etické "normy" a "hodnoty" jako védecký a filosofický problém [Ethical "norms" and "values" as a scientific and philosophical problem]. Archive of Ladislav Hejdánek.

Hejdánek, L. (1997). Neprédmétnost v myšlení a ve skutečnosti [Objectivity in thinking and in reality]. Prague: Oikoymenh.

Hejduk, T. (2012). Idea university na střední škole [The idea of a secondary-school university]. Pedagogika, 62(3), 339-345.

Holland, R. F. (1980). Education and value. In Against empiricism. Oxford: Basil Blackwell. Chappell, T. (2014). Knowing what to do. Oxford University Press.

Kilpatrick, W. (1992). Why Johnny can't tell right from wrong: Moral illiteracy and the case for character education. New York: Simon \& Schuster.

Komárková, B. (1997). Reformace a moderní stát [Reformation and the modern state]. In Lidská práva [Human rights] (pp. 49-57). Heršpice: Eman.

Květina, J. (2016). Koncepce liberalismu a demokracie v edukačním procesu: dekonstrukce neoliberální dominance v RVP [Conceptions of liberalism and democracy in the educational Process: A deconstruction of neo/liberal dominance in the RVP (Framework Educational Plan)]. Pedagogika, 66(3), 312-329.

Lickona, T. (1992). Educating for character: How our schools can teach respect and responsibility. New York: Bantam.

Newman, J. H. (1996). The idea of a university. Yale University Press.

Oakeshott, M. (2003). The idea of a university. Academic Questions, 17(1).

Patočka, J. (1996). Filosofie výchovy [Philosophy of education]. In J. Patočka, Péče o duši I [Soul Care I]. Praha: Oikoymenh.

Patočka, J. (1996a). Harmonismus moderních humanist [Harmonism of modern humanists]. In J. Patočka, Péće o duši I [Soul Care I]. Praha: Oikoymenh.

Patočka, J. (1996b). Mládí a filosofie [Youth and philosophy]. In J. Patočka, Péče o duši I [Soul Care I]. Praha: Oikoymenh.

Patočka, J. (2012). Platónova péce o duši a spravedlivý stát [Plato's care of the soul and a just state]. Praha: Oikoymenh.

Petrusek, M. (2007). Vychováváme člověka vzdělaného nebo informovaného? Současné vzdělávací systémy $v$ čase postmodernity [Do we raise an educated or informed person? 
Contemporary educational systems in the time of postmodernity]. (Lecture). Conference Jan Amos Komenský - 350 let od vydání Opera Didactica Omnia [350 years since the release of Opera Didactica Omnia], Prague, November 15-17, 2007.

Rorty, R. (2000). The moral purposes of the university: An exchange. The Hedgehog Review, 2(3), 106-119.

Shils, E. (1997). The calling of education: The academic ethic and other essays on higher education. Chicago: University of Chicago Press.

Strauss, L. (1995). What is liberal education? In Liberalism Ancient and Modern. University of Chicago Press.

Svobodová, Z. (2012). Škola a vzdělávání v oblasti etiky: K etické výchově jako školnímu predmětu [School and education in the field of ethics: To ethical education as a school subject]. In Z. Svobodová (ed.), Dưstojně a radostně [With dignity and joy]. Středokluky: Zdeněk Susa.

Štech, S. (2011). Profesionalita učitele v neoliberální době [Teacher's professionalism in the neoliberal era]. (Lecture). Meeting of the Lípa Association in Lázně Bělohrad, November 25-27, 2011. Available from: http://www.lipa.cz/doc/28/01.pdf.

Thiessen, E. J. (1993). Teaching for commitment: Liberal education, indoctrination, and Christian nurture. Montreal and Kingston: McGill-Queen's University Press.

Various authors (2007), Rámcový vzdělávací program pro gymnázia [The Czech National School Curriculum]. Prague: VÚP.

Winner, L. (1994). Three paradoxes of the information age. In G. Bender \& T. Druckrey (Eds.), Culture on the brink. Seattle: Bay Press.

Williams, B. (2005). In the beginning was the deed. Princeton: Princeton University Press.

Williams, B. (2006). What might philosophy become? In B. Williams, Philosophy as a humanistic discipline. Princeton: Princeton University Press.

Znoj, M., Bíba, J., \& Vargovčíková, J. (2014). Demokracie v postliberální konstelaci [Democracy in a post-liberal constellation]. Prague: Karolinum.

Doc. Tomás Hejduk, Ph.D.

University of Pardubice, Department of Philosophy \& Researcher at Centre for Ethics;

e-mail: tomas.hejduk@upce.cz 